\title{
Indonesia in a Pandemic: A Book Review "Bunga Rampai Covid-19: Tinjauan dari Aspek Kesehatan, Ekonomi dan Hukum"
}

\author{
Rizqi Mulyani Slamet \\ Faculty of Law, Universitas Negeri Semarang \\ Email: rizqi.mulyanislamet06@gmail.com
}

\section{Citation:}

Slamet, R. M. (2021). Indonesia in a Pandemic: A Book Review "Bunga Rampai Covid-19: Tinjauan Dari Aspek Kesehatan, Ekonomi Dan Hukum". Lex Scientia Law Review, 5(2), 137-142, doi: https://doi. org/10.15294/lesrev. v5i2.51710

\section{History of Article}

Received: November 9, 2021

Revised: November, 11, 2021

Accepted: November 10, 2021

(C) The Author(s)

\section{(c) (i) (2) (2)}

This work is licensed under a Creative Commons Attribution-NonCommercial-ShareAlike 4.0 International License.

All writings published in this journal are personal views of the authors and do not represent the views of this journal and the author's affiliated institutions.

Lex Scientia Law Review published by Faculty of Law, Universitas Negeri Semarang, Indonesia in collaboration of UKM Lex Scientia. Published biannually every May and November.

\author{
BOOK DATA \\ Book title : Bunga Rampai Covid- \\ 19: Tinjauan Dari Aspek \\ Kesehatan, Ekonomi \\ Dan Hukum \\ Author \\ : Prof. Dr. dr. Anies, \\ M.Kes., PKK; Dr. Retno \\ Setyowati, S.E., M.M.; \\ dr. Naela Fadhila, \\ M.Kes.; Kamal Arif, \\ S.H., M.H. \\ Publisher : Gosyen Publishing \\ Publication Year : 2021 \\ Publication City : Yogyakarta \\ Book Language : Indonesia \\ Number of pages : 198 \\ Book ISBN ： 978-602-5411-98-4 \\ KEYWORDS \\ Covid-19; Economic Slowdown; Health Protocol; \\ New Normal; Pandemic
}




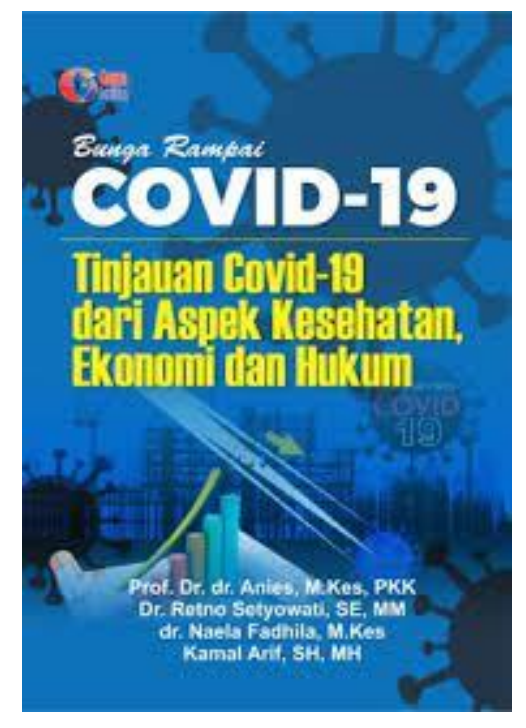

This book is written in an anthology or anthology consisting of articles with the same theme by several authors, namely Prof. Dr. dr. Anies, M.Kes., PKK; Dr. Retno Setyowati, S.E., M.M.; dr. Naela Fadhila, M.Kes.; and Kamal Arif, S.H., M.H. The book, in English, entitled Anthology Covid-19 Overview from Health, Economics and Legal Aspects, discusses the ins and outs of Covid19. There are three aspects of Covid-19 discussed in this book, namely aspects of health and medicine, economics, and law. This book explains that Covid19 is caused by SARS-CoV-2, a new type of virus from a group of viruses that infect the respiratory system (coronavirus). Covid-19 can infect anyone but has a more dangerous effect on the elderly, pregnant women, smokers, people with specific diseases, and weak immune systems. The symptoms of exposure to Covid-19, in general, include fever, dry cough, and shortness of breath, as well as other symptoms that can appear. A rapid test or PCR (Polymerase Chain Reaction) is needed to ensure the symptoms are Covid-19, but there can be confirmed positive but do not experience symptoms. People who have no symptoms and risk contracting it from people who are confirmed to have Covid-19 are referred to as OTG (Asymptomatic People).

Covid-19 is a very worrying pandemic. In case of spread, the number of sufferers and cases of death due to Covid-19 is increasing every day. The handling of the outbreak is still in the form of breaking the chain of spread because there is no medicine or vaccine yet, so treatment in the hospital is only to increase the body's immunity. Comprehensive and appropriate efforts are needed considering the spread of this virus is a health and humanitarian problem that impacts aspects of life. In addition, there is uncertainty regarding the extent of the spread and the length of the pandemic period, which impacts slowing national economic growth, decreasing state revenues, and increasing financing so that government efforts are needed to save health and the national economy. To deal with threats that endanger the national economy and/or financial system stability, the government issued Government Regulation in lieu of Law (hereinafter as Perppu) Number 1 of 2020 concerning State Financial Policy and Financial System Stability for Handling the 2019 Corona Virus Disease Pandemic.

Law Number 24 of 2007 concerning Disaster Management states that a disaster is an event that threatens and disrupts the community, both caused by natural, non-natural, and human factors which cause casualties, 
environmental damage, property, and psychological impacts. The Covid-19 pandemic is included in Article 1 paragraph (3) of the law, which states non-natural disasters. The government has made efforts to break the chain of the spread of Covid-19, including contact tracking or contact tracing carried out by people who have met with sufferers to make it easier for health workers to take action, WHO states that contact tracking is carried out in three ways, such as identifying contacts, recording contacts, and contact follow-up. Contact tracking is considered quite adequate for the spread because people who have a large percentage exposed to Covid-19 immediately receive treatment.

In August 2020, 230 families in five major cities in Indonesia transmitted the coronavirus to each other. It started two months after the government relaxed the Large-Scale Social Restrictions (PSBB) policy. The current pandemic has challenges for family life, including psychosocial pressure, personal and family economics, future uncertainty, limited personal psychological space due to sharing space while at home. However, every family member plays an essential role in preventing this cluster of spread. The easing of policies also increases office clusters and even offices in Jakarta and some areas of Central Java in the red zone. There are still many offices that do not have a Work From Home policy, employees who are positive for Covid-19 both exposed outside the office and inside, and the lack of discipline in complying with health protocols in the office area. The steps that companies can use to survive a pandemic include innovation and risk-taking. Products can be produced and distributed without neglecting the health and safety of workers, building mental and emotional health of workers amid changes in customer behavior, and providing a sense of security and comfort in situations of uncertainty, namely in addition to high-end results, health, and safety, as well as good teamwork through more effective communication.

The discourse regarding the new normal or the new normal has just begun to be widely reported. Some people feel anxious, while others welcome it with joy. It is in line with the World Health Organization (WHO) warning that Covid-19 may never go away even if a vaccine is found because vaccines only control the virus. Of course, if Covid-19 never goes away, it will be people who have to adjust to new conditions. There are conditions to carry out the new normal, namely a decrease in positive cases and cases of death, the availability of test services, both rapid tests and PCR, access to adequate services, including the availability of medical devices. In addition, WHO has stricter requirements, such as evidence that transmission in its territory can be 
controlled and providing input to the community in the new normal transition process.

Guidelines for dealing with the new normal are regulated in the Circular Letter of the Minister of Health Number HK.02.01/MENKES/335/2020 concerning the Protocol to Prevent the Transmission of Covid-19 in the Workplace of the Service and Trade Sector (public area). The new standard can be implemented in the family environment through education on new normal and Covid-19, maintaining communication to know each other's health conditions, and prioritizing health protocols even at home. Furthermore, health services must be ready to face the new normal while simultaneously caring for Covid-19 patients and serving general patients with minimal risk of transmission. However, the level of hospital readiness, availability of facilities, availability of Personal Protective Equipment, and different knowledge of health workers regarding the Covid-19 protocol can potentially spread the virus further. The key to the success of the new normal is the discipline of each individual in obeying the protocol.

The government predicted that the pandemic would reduce economic growth in the second quarter of 2020 to $3.8 \%$. If it continues in the third quarter of 2020, Indonesia has the potential to experience a recession. A recession can be interpreted as a significant decline in economic activity that occurs in a few months. Several countries have reported an economic recession, including South Korea, Germany, Singapore, France, Italy, and the United States. This recession indicator can be seen from the decline in Gross Domestic Product (GDP), a decline in real income, the number of jobs, retail sales, and a slumping manufacturing industry sharply as GDP declined.

If it is not stopped, bank credit will fail, it will be difficult to control inflation, and deflation can occur. The government must choose to focus on handling the epidemic or saving the economy. The easing of PSBB as a form of saving the economy has created a new cluster of Covid-19 and has not been able to increase economic growth. During this period, there is an opportunity for the business world by utilizing the digital economy whose marketing can be more comprehensive with the help of social media platforms as well as the opening of new businesses in the health sector as a result of the increasing demand for medicines, disinfectant liquids, hand sanitizers, masks, personal protective equipment, and medical gloves. It can be concluded that the chance of Indonesia experiencing a recession or not depends on the handling of Covid-19.

This Covid-19 Anthology Book Overview from Health, Economics, and Legal Aspects have advantages and disadvantages. The drawback of this book 
is the presentation of each chapter is short and repetition of the previous presentation in some parts. The advantage of this book is that it provides knowledge related to Covid-19 and how the government and society respond to it, which is contained in one book. In addition, the language used in this book is easy to understand so that the general public can read it. Overall this book is good enough to be used as reading material related to Covid-19.

The benefit of this book is the emergence of awareness that Covid-19 is a pandemic that must be tackled together. The community and the government must work together so that the chain of the virus does not spread further. The government has issued several regulations to deal with the pandemic. Meanwhile, public compliance with regulations is urgently needed. Health protocols that are not appropriately implemented, carrying out extreme mobility, and so on can increase in positive cases of Covid-19. If the pandemic cannot be stopped, then the new normal will be an option. Aspects of life affected by the pandemic must be restored immediately to prevent the negative impact from getting bigger. 


\section{LEGAL ADAGE}

\section{IGNORANTIA JURIS \\ NON EXCUSAT}

\section{Ignorance of Law Excuses No One}

